\title{
Strategic Treaty Shopping
}

December 2014 | Sunghoon Hong 
Korea Institute of Public Finance

1924, Hannuri-daero, Sejong, 339-007, Korea

Tel: 82-44-414-2114 Fax: 82-44-414-2179

URL: www.kipf.re.kr

(C) 2014 KIPF 


\section{Strategic Treaty Shopping}

December 2014

Sunghoon Hong

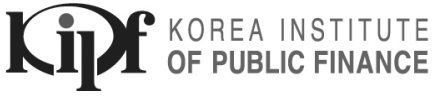




\section{Contents}

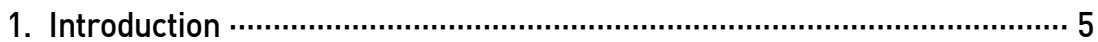

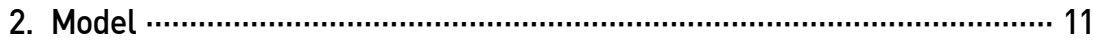

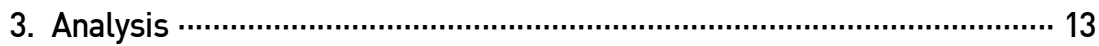

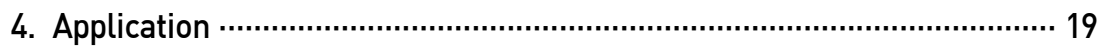

4.1. Tax-minimizing routes ………........................................... 19

4.2. Centrality measures …….............................................. 24

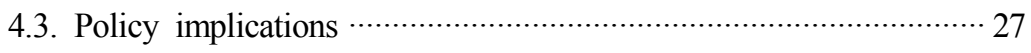

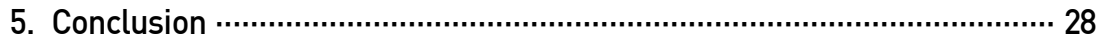

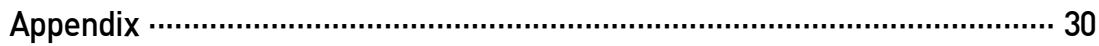

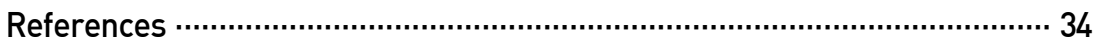




\section{List of Tables}

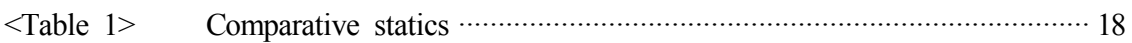

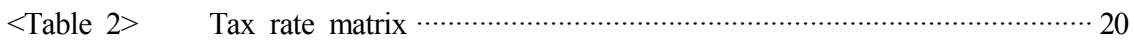

$<$ Table 3> Tax-minimizing investment routes ………………………………... 22

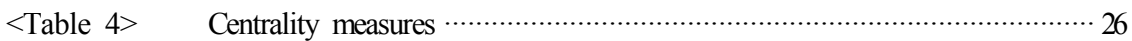

Appendix

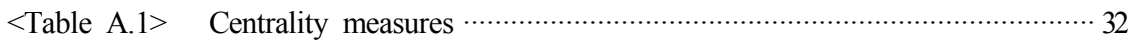

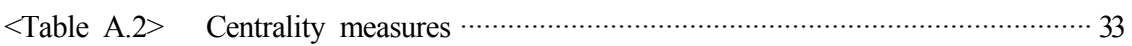




\section{List of Figures}

\section{Appendix}

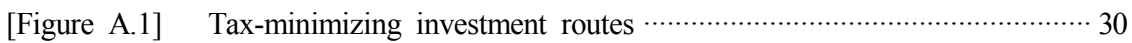

[Figure A.2] Tax-minimizing investment routes …………............................... 31 


\section{Introduction}

The main purpose of a tax treaty is to mitigate double taxation by reducing rates of withholding tax imposed on income and capital earned across national borders. To promote international trade and investment, countries maintain extensive and complex tax treaty networks. For example, South Korea has more than 80 tax treaties in force with various reduced rates from five to fifteen percent depending on contracting countries and income types. ${ }^{1}$ However, due to the complexity of tax treaty networks, combined with the diverse structures of national tax laws, unintended situations may occur. One such situation is an abuse of tax treaties for tax evasion and avoidance, which is often called treaty shopping. Generally, treaty shopping refers to a situation in which an individual or a company that is not eligible for the benefits of a tax treaty uses an intermediary entity that is eligible for such benefits to obtain these benefits indirectly.

More precisely, treaty shopping may occur in circumstances such as the following: An individual or a company, who is a resident of country 1, establishes an intermediary entity in country 2 to operate a business and earn a type of income, such as dividends, interest, royalties, and capital gains, in country 3. Countries 2 and 3 have a tax treaty that reduces taxes on the type of income earned in country 3 while countries 1 and 3 do not have such a treaty. ${ }^{2}$ Countries 1 and 2 also have a favorable tax treaty. The intermediary entity claims the application of the tax treaty between countries 2 and 3 to obtain tax reductions in country 3 . However, the intermediary entity is owned or controlled by a resident of country 1 who is not entitled to the tax treaty benefits. Furthermore, the intermediary entity pays no or low taxes in country 2 on the type of income earned in country 3. The intermediary entity carries on no substantial business in country 2. In these circumstances, in country 3, a tax authority may be able to apply a general anti-abuse rule

\footnotetext{
${ }^{1}$ As of December 2013, the United States has 66 tax treaties in force; China 96 treaties; the United Kingdom 126 treaties with reduced rates from zero to 25 percent.

${ }^{2}$ Countries 1 and 3 may have no tax treaty or have a less favorable tax treaty.
} 
and impose a penalty on the resident of country 1 for tax avoidance. ${ }^{3}$

Treaty shopping is generally considered to be an improper use of tax treaties. ${ }^{4}$ This paper analyzes treaty shopping with a game-theoretic model in tax treaty networks. I would like to address the following questions: How can investment routes be designed internationally for tax minimization? How frequently do investors use such routes? How much does this affect tax revenue in a source country? Which countries play significant roles in tax-minimizing investment routes? Which tax treaties do countries need to amend to prevent treaty shopping?

Let us imagine a world with $n$ countries. An investor lives in country 1 and plans to invest in country $n$. From this investment the investor will earn a type of income in country $n$ and repatriate his income to country 1 . The investor intends to minimize tax, i.e., to maximize his after-tax income, by choosing an investment route from country 1 to country $n$. The investor can choose a direct route or an indirect route, which incorporates intermediary entities established in other countries. Tax treaties, as well as national tax laws, determine tax rates on cross-border payments. In turn these tax rates determine taxes paid along an investment route. Meanwhile, in country $n$, a tax agency is informed of this inbound investment. However, the tax agency does not know which route the investor chose. The tax agency can choose to audit the investor to find out the investment route. While the audit is costly, it can give additional revenue to the tax agency if it reveals that the investor chose an indirect route for tax avoidance. The tax agency imposes a penalty tax on the investor by applying a general anti-avoidance rule. However, if the investor chose the direct route, the tax agency does not gain additional revenue from the audit but incurs the cost of the audit. This situation can

\footnotetext{
${ }^{3}$ General anti-abuse rules allow tax authorities to recharacterize a series of transactions mainly designed to obtain tax benefits as one taxable transaction. For instance, see Section $\S 7701$ (o) of the Internal Revenue Code of the United States; Part 5 of Finance Act 2013 of the United Kingdom; Article 14 (3) of Basic Act for National Taxes of South Korea.

${ }^{4}$ OECD (2013) states that treaty abuse is one of the most important sources of concerns regarding Base Erosion and Profit Shifting (BEPS). In this OECD report, action 6 deals with issues on how to prevent treaty abuse.
} 
be modeled as a simultaneous-move game between the tax agency and the investor in a network of tax treaties.

First I characterize the (Nash) equilibrium of this model. In equilibrium the investor chooses either the direct route or tax-minimizing indirect routes. For the investor, it is a dominated strategy to choose an indirect route that is not tax-minimizing. Furthermore, there is no pure-strategy equilibrium because no player wants to let the other player predict his choice with certainty. Thus, in equilibrium, both players choose mixed strategies. The equilibrium probability $p$ of the tax agency auditing the investor is calculated with parameters of the model such as tax rates. The equilibrium probability $q$ of the investor choosing tax-minimizing indirect routes is calculated as the ratio of audit cost to penalty tax. I also calculate the equilibrium payoffs of the players. By subtracting the equilibrium payoff of the tax agency from the maximum tax revenue achieved when only the direct route is available, I compute the loss of tax revenue from treaty shopping in my model. This equilibrium loss of tax revenue is determined by the tax rate spread, which is defined as the difference of withholding tax rates imposed by the source country in the direct route and in a tax-minimizing indirect route. Interestingly, if the penalty tax rate is greater than the tax rate spread, the tax agency raises more revenue by adopting the equilibrium random audit strategy than by sticking to non-random audit strategies.

The comparative statics of the equilibrium also shows interesting implications. As the tax rate of a tax-minimizing indirect route increases, $p$ decreases, i.e., the tax agency audits the investor less frequently. As the tax rate of the direct route increases, $p$ increases, i.e., the tax agency audits the investor more frequently. As the tax rate of the residence country increases, $p$ decreases, i.e., the tax agency audits the investor less frequently. However, in each of these cases, $q$ remains unchanged. This is because the tax agency adjusts the equilibrium audit probability $p$ to make the investor stay indifferent between the direct route and tax-minimizing indirect routes.

Next I examine the structure of tax-minimizing investment routes in a 
real-world network of tax treaties between fifteen selected countries: Belgium, Bermuda, Cayman Islands, China, Hong Kong, Ireland, Japan, South Korea, Luxembourg, the Netherlands, Saudi Arabia, Singapore, Switzerland, the United Kingdom, and the United States. Tax treaties between these countries, as well as their national tax laws, specify rates of withholding tax on various types of income, such as dividends, interest, royalties, and capital gains. In the context of international taxation, a withholding tax refers to a tax on income and capital imposed by a source country. The rates of withholding tax can be reduced by tax treaties. Here I focus on the rates of withholding tax on dividends by presuming that investors establish companies to earn their income as dividends.

If foreign investors plan to invest in countries with no withholding tax on dividends, they can minimize tax by investing directly. However, if there is a withholding tax on dividends, foreign investors may be able to minimize tax by investing indirectly, e.g., by investing through intermediary entities established in other countries. Among the fifteen countries, eight countries impose withholding taxes on dividends: Belgium, China, Japan, South Korea, the Netherlands, Saudi Arabia, Switzerland, and the United States. I construct a matrix of withholding tax rates and analyze tax-minimizing investment routes to these countries. I also calculate tax rate spreads, which can be viewed as a proxy for tax revenue loss due to strategic treaty shopping.

In total I discover 177 tax-minimizing indirect routes between all pairs of countries. While some pairs of countries have no such indirect route between them (because direct routes are tax-minimizing), other pairs often have more than one tax-minimizing indirect route. About 75 percent (134 routes) of tax-minimizing indirect routes pass through one of five countries with no withholding tax: Hong Kong, Ireland, Luxembourg, Singapore, and the United Kingdom. These indirect routes can maximize an investor's aftertax income because there are source countries that set the minimum tax treaty rate for these countries. However, about 21 percent (38 routes) of taxminimizing indirect routes pass through any one of Belgium, the Netherlands, 
or Switzerland. These countries play a significant role as a pass-through country in international investments by maintaining tax treaties favorable to certain residence countries, such as Japan, while generally imposing withholding taxes.

Network centrality measures are introduced to assess the importance of a country in tax-minimizing investment routes. Each centrality measure ranks countries in a different way. However, by all the three aggregate centrality measures introduced here, the United Kingdom and Ireland are ranked first and second, respectively. These two countries are followed by Hong Kong, Luxembourg, and Switzerland in aggregate centrality rankings.

Some countries aim to prevent treaty shopping by amending tax treaties to include anti-treaty shopping provisions. ${ }^{5}$ Because pass-through countries can be identified by analyzing tax-minimizing investment routes, countries may focus on some tax treaties with pass-through countries, which can be abused for treaty shopping. Countries may also assign priorities to certain tax treaties based on centrality measures. However, countries need to amend tax treaties with all possible pass-through countries, because otherwise investors will switch to safer tax-minimizing routes, which will not be affected by the amended treaties.

The contribution of this paper is twofold.

Firstly, this paper contributes to the body of literature on the economics of international taxation. The main focus of this literature has been on strategic interactions between countries, which can choose tax rates, as well as tax relief rules, such as foreign tax credit and deduction. Bond and Samuelson (1989) introduce a model where countries can apply differentiated tax rates on foreign income, and show that a certain relief rule can achieve a higher

\footnotetext{
${ }^{5}$ OECD (2012) provides the commentary on Article 1 of the OECD model tax convention, which discusses anti-abuse provisions. Examples of such provisions are limitation on benefits and main purpose test clauses.
} 
level of world welfare than other rules. ${ }^{6}$ Another focus of this literature is to examine theoretical and empirical relations between tax treaties and Foreign Direct Investment (FDI). For instance, Chisik and Davies (2004) study the effects of FDI on tax treaty bargaining by using a cooperative bargaining solution, and show that asymmetry in FDI stocks may lead to higher tax treaty rates. ${ }^{7}$ In contrast to these existing studies, this paper analyzes the network effects of tax treaty rates on strategic interactions between a taxpayer and a tax authority by combining a game-theoretic model with a network analysis.

Secondly, this paper contributes to the literature on tax havens and international tax avoidance. This growing body of literature includes both positive and negative views on the effects of tax havens on world economy. Slemrod and Wilson (2009) develop a model of tax competition where countries can choose tax rates and expenditures on tax enforcement while firms can choose to conceal their income in tax havens, and show that the elimination of all tax havens can increase the welfare of all countries. Desai et al. (2006) empirically examine the characteristics of American multinational companies with affiliates in tax havens, and discover that tax havens are used more intensively by companies with more intra-firm trade and larger R\&D investment. ${ }^{8}$ However, these existing studies have dealt with the general relationship between tax havens and tax avoidance. In contrast, this paper focuses on a specific type of tax avoidance behavior, treaty abuse, and examines the role of tax havens in treaty abuse.

The rest of this paper is organized as follows. Section 2 introduces a

\footnotetext{
${ }^{6}$ For related studies, see Feldstein and Hartman (1979), Janeba (1995), Konan (1997), and Davies (2003). Becker and Davies (2014) develop a model of tax-induced transfer pricing where a multinational firm can participate in the negotiation of transfer pricing disputes between residence and source (or host) countries. The relative negotiation power of the two countries can affect the equilibrium transfer price, which is shown to increase in the tax rate of the source country and to decrease in the tax rate of the residence country.

${ }^{7}$ Conversely, Blonigen and Davies (2004) examine the effects of tax treaties on inbound and outbound FDI stocks in the United States, and discover substantial heterogeneity in treaty effects across contracting countries though the average treaty effect is not statistically significant.

${ }^{8}$ Dharmapala (2008) provides an overview of the literature on tax havens. For related studies, see Hines and Rice (1994), Clausing (2009), Desai and Dharmapala (2009, 2011), Dharmapala and Hines (2009), Gravelle (2009), and Hong and Smart (2010).
} 
game-theoretic model in a network of tax treaties. Section 3 analyzes the equilibrium of this model and calculates tax revenue loss due to treaty shopping. Section 4 examines the structure of tax-minimizing investment routes in a real-world network of tax treaties between selected countries and discusses how to prevent treaty shopping. Section 5 concludes.

\section{Model}

Let us imagine a world with $n \geq 3$ countries. An investor lives in country 1 and plans to invest in country $n$. From this investment the investor will earn a type of income $m>0$ in country $n$ and repatriate his income to country 1 . Country 1 is called the residence country while country $n$ is called the source country. The investor intends to minimize tax when he remits his income to country 1, i.e., the investor intends to maximize his after-tax income in the residence country. The investor can choose an investment route (or simply a route) from country 1 to country $n$. Formally, a route is defined as a sequence of countries, $1, i, \ldots, j, n$, from country 1 to country $n$. If the investor chooses a direct route $1, n$, he invests directly in country $n$. If the investor chooses an indirect route $1, i, \ldots, j, n$, he invests in country $n$ by establishing entities in countries $i$ through $j$ and making his investment through these entities. Given an indirect route $1, i, \ldots, j, n$, countries $i$ through $j$ are called passthrough countries. When the investor remits his income from country $n$ to country 1 , the remittance route follows the reverse order of the countries in the investment route.

Here I assume that the investor will earn income $m$ as dividends. The investor knows a tax rate $t_{i}$ in country $i$ and a tax rate $t_{i j}$ on dividends under the tax treaty between countries $i$ and $j$. A withholding tax is imposed by country $i$ at the tax treaty rate $t_{i j}$ when an entity in country $i$ remits dividends to another entity in country $j$. A tax rate matrix is defined as follows: 


$$
T=\left[\begin{array}{cccc}
t_{1} & t_{12} & \cdots & t_{1 n} \\
t_{21} & t_{2} & \cdots & t_{2 n} \\
\vdots & \vdots & \ddots & \vdots \\
t_{n 1} & t_{n 2} & \cdots & t_{n}
\end{array}\right]
$$

In country 1 , if the investor chooses the direct route $1, n$, the after-tax income is $\left(1-t_{n 1}\right)\left(1-t_{1}\right) m$. However, if the investor chooses an indirect route $1, i, \ldots, j, n$, the after-tax income is $\left(1-t_{n j}\right)\left(1-t_{j}\right) \cdots\left(1-t_{i}\right)\left(1-t_{i 1}\right)\left(1-t_{1}\right) m$.

In country $n$ a tax agency is informed of the inbound investment. The tax agency knows that the investor is a resident of country 1 and expects that the investor's earning will be $m$ in country $n$. However, the tax agency does not know which route the investor chose to invest in country $n$. When the investor chooses the direct route $1, n$, the revenue of the tax agency is $t_{n 1} m$. However, when the investor chooses an indirect route $1, i, \ldots, j, n$, the revenue of the tax agency is $t_{n j} m$.

The tax agency can choose whether to audit the investor to find out the investment route. The cost of audit is $c>0$. After the audit, if the tax agency finds that the investor chose an indirect route, the tax agency imposes a penalty tax on income $m$ at rate $r$ by applying a general anti-avoidance rule. The investor must pay the penalty tax $r m$ to the tax agency. I assume that the cost of audit is smaller than the penalty tax, i.e., $c<r m$. If the tax agency finds that the investor chose the direct route, the tax agency receives no additional revenue.

When choosing whether to audit the investor, the tax agency does not know which route the investor chose. When choosing the investment route, the investor does not know whether the tax agency will audit. Thus, it is reasonable to assume that the tax agency and the investor play a simultaneousmove game.

The tax agency (or player A) chooses a strategy $a \in\{0,1\}$ to specify whether to audit the investor. If $a=1$, the tax agency audits the investor. Otherwise, the tax agency does not. The investor (or player B) chooses a strategy $b$ to specify the investment route from country 1 to country $n$. 
If $b=1, n$, the investor chooses the direct route. Otherwise, the investor chooses an indirect route $b=1, i, \ldots, j, n$. The tax rate of an investment route $b$ is defined as follows:

$$
t(b)= \begin{cases}t_{n 1} & \text { if } b=1, n \\ 1-\left(1-t_{n j}\right)\left(1-t_{j}\right) \cdots\left(1-t_{i}\right)\left(1-t_{i 1}\right) & \text { if } b=1, i, \ldots, j, n\end{cases}
$$

To summarize, the payoff functions of the tax agency (A) and the investor (B) can be written as follows:

(i) $a=1$ and $b=1, i, \ldots, j, n$

$$
u_{A}(a, b)=t_{n j} m+r m-c \text { and } u_{B}(a, b)=(1-t(b))\left(1-t_{1}\right) m-r m
$$

(ii) $a=1$ and $b=1, n$

$$
u_{A}(a, b)=t_{n 1} m-c \text { and } u_{B}(a, b)=(1-t(b))\left(1-t_{1}\right) m
$$

(iii) $a=0$ and $b=1, n$

$$
u_{A}(a, b)=t_{n 1} m \text { and } u_{B}(a, b)=(1-t(b))\left(1-t_{1}\right) m
$$

(iv) $a=0$ and $b=1, i, \ldots, j, n$

$$
u_{A}(a, b)=t_{n j} m \text { and } u_{B}(a, b)=(1-t(b))\left(1-t_{1}\right) m
$$

\section{$3 \quad$ Analysis}

In this section I characterize the (Nash) equilibrium of the model and calculate the expected loss of tax revenue in the equilibrium.

Given a tax rate matrix $T$, a route $b^{*}$ is tax-minimizing if for every route $b, t\left(b^{*}\right) \leq t(b)$. Given $T$, among all possible routes, a tax-minimizing route $b^{*}$ can be obtained. Here I assume that there is a tax-minimizing indirect route $b^{*}$ such that $t\left(b^{*}\right)<t_{n 1}$. Thus, the direct route is not tax-minimizing. Because $t\left(b^{*}\right)<t_{n 1}$ implies $\left(1-t_{n 1}\right)\left(1-t_{1}\right) m<\left(1-t\left(b^{*}\right)\right)\left(1-t_{1}\right) m$, the investor can earn higher after-tax income by choosing $b^{*}$ than by choosing the direct route. I also assume that $\left(1-t\left(b^{*}\right)\right)\left(1-t_{1}\right)-\left(1-t_{n 1}\right)\left(1-t_{1}\right)<r$, i.e., the penalty tax rate is greater than the difference in rates of after-tax income. 


\section{4}

The investor prefers the direct route if he will have to pay the penalty tax after using $b^{*}$.

Now I show that there is a unique equilibrium where the tax agency and the investor play mixed strategies. The equilibrium probability of the tax agency auditing the investor is calculated with model parameters such as tax rates. The equilibrium probability of the investor choosing tax-minimizing indirect routes is calculated as the ratio of audit cost to penalty tax.

Theorem 1. If there is a unique tax-minimizing indirect route $b^{*}$, there is a unique equilibrium where the tax agency audits the investor with probability $p$ and the investor chooses the indirect route $b^{*}$ with probability $q$ specified as follows:

$$
\begin{gathered}
p=\frac{\left(1-t\left(b^{*}\right)\right)\left(1-t_{1}\right)-\left(1-t_{n 1}\right)\left(1-t_{1}\right)}{r} \\
q=\frac{c}{r m}
\end{gathered}
$$

If there is more than one tax-minimizing indirect route, in equilibrium, $q$ is the total probability of the investor choosing tax-minimizing indirect routes. The tax agency's equilibrium strategy remains the same.

Proof of Theorem 1. This proof proceeds in four steps.

Step 1. Find dominated strategies. Let $b$ denote an indirect route that is not tax-minimizing. Because $b^{*}$ is tax-minimizing, $(1-t(b))\left(1-t_{1}\right) m<$ $\left(1-t\left(b^{*}\right)\right)\left(1-t_{1}\right) m$, which implies that $u_{B}(0, b)<u_{B}\left(0, b^{*}\right)$ and $u_{B}(1, b)<$ $u_{B}\left(1, b^{*}\right)$. Regardless of whether the tax agency audits the investor $(a=1)$ or not $(a=0)$, the investor is better off by choosing $b^{*}$ than by choosing $b$. Thus, $b$ is dominated by $b^{*}$. Note that in equilibrium the investor does not play a dominated strategy. Therefore, in equilibrium, the investor will choose either the direct route or a tax-minimizing indirect route.

Step 2. Show that there is no pure-strategy equilibrium. Given $a=1$, because $\left(1-t\left(b^{*}\right)\right)\left(1-t_{1}\right)-r<\left(1-t_{n 1}\right)\left(1-t_{1}\right)$, the investor's best response 
is to choose the direct route $b=1, n$. Given $b=1, n$, because $c>0$, the tax agency's best response is no audit $a=0$. Given $a=0$, because $\left(1-t_{n 1}\right)\left(1-t_{1}\right)<\left(1-t\left(b^{*}\right)\right)\left(1-t_{1}\right)$, the investor's best response is to choose a tax-minimizing indirect route $b^{*}$. Given $b^{*}$, because $c<r m$, the tax agency's best response is to audit $a=1$. Thus, there is no pure-strategy equilibrium.

Step 3. Suppose that there is a unique tax-minimizing indirect route $b^{*}$. It is sufficient to show that each player is indifferent between the pure strategies played with positive probability. Given $p$, the investor is indifferent between the direct route $b=1, n$ and the tax-minimizing indirect route $b^{*}=1, i, \ldots, j, n$, because $u_{B}(p, b)=\left(1-t_{n 1}\right)\left(1-t_{1}\right) m=u_{B}\left(p, b^{*}\right)$. Given $q$, the tax agency is indifferent between no audit $a=0$ and audit $a=1$, because $u_{A}(0, q)=t_{n 1} m-\frac{c}{r}\left(t_{n 1}-t_{n j}\right)=u_{A}(1, q)$. Therefore, $(p, q)$ characterizes a unique equilibrium.

Step 4. Suppose that there are $\ell \geq 2$ tax-minimizing indirect routes. Each of the tax-minimizing indirect routes is denoted by $b^{k}=1, i_{k}, \ldots, j_{k}$, $n$, where $k=1, \ldots, \ell$, and is played with probability $q_{k}$, where $\sum_{k=1}^{\ell} q_{k}=q$. Given $\left(q_{1}, \ldots, q_{\ell}\right)$, the tax agency is indifferent between no audit $a=0$ and audit $a=1$, because $u_{A}\left(0,\left(q_{1}, \ldots, q_{\ell}\right)\right)=t_{n 1} m-\sum_{k=1}^{\ell} q_{k}\left(t_{n 1}-t_{n j_{k}}\right) m=$ $u_{A}\left(1,\left(q_{1}, \ldots, q_{\ell}\right)\right)$. Given $p$, the investor is indifferent between the direct route $b=1, n$ and a tax-minimizing indirect route $b^{k}=1, i_{k}, \ldots, j_{k}, n$, because $u_{B}(p, b)=\left(1-t_{n 1}\right)\left(1-t_{1}\right) m=u_{B}\left(p, b^{k}\right)$. Therefore, $\left(p,\left(q_{1}, \ldots, q_{\ell}\right)\right)$ characterizes a unique equilibrium.

For the investor, it is a dominated strategy to choose an indirect route that is not tax-minimizing. Because players do not choose a dominated strategy in equilibrium, the investor will only choose either the direct route or a tax-minimizing indirect route.

If the tax agency audits the investor for sure, the investor would choose the direct route, because he will have to pay a penalty if he chooses a taxminimizing indirect route. If the investor chooses the direct route for sure, 
the tax agency would not audit the investor, because the audit is costly and it cannot generate additional revenue for the tax agency. If the tax agency does not audit the investor for sure, the investor would choose a tax-minimizing indirect route $b^{*}$, because $b^{*}$ maximizes the investor's after-tax income if there is no penalty tax. Finally, if the investor chooses a tax-minimizing indirect route $b^{*}$ for sure, the tax agency would audit the investor and impose a penalty for tax avoidance. Thus, there is no pure-strategy equilibrium.

However, by choosing a mixed strategy, players can make each other indifferent between the pure strategies played with positive probability, and reach a mixed-strategy equilibrium. In equilibrium the tax agency chooses a mixed strategy, characterized by probability $p$, to make the investor indifferent between the direct route and tax-minimizing indirect routes. The investor also chooses a mixed strategy, characterized by probability $q$, to make the tax agency indifferent between no audit and audit.

By subtracting the tax agency's equilibrium payoff from the maximum possible revenue, I compute the equilibrium loss of tax revenue in my model.

Remark 1. If there is a unique tax-minimizing indirect route $1, i, \ldots, j, n$, in equilibrium, the tax agency's payoff is $t_{n 1} m-\frac{c}{r}\left(t_{n 1}-t_{n j}\right)$. The tax agency's revenue would be $t_{n 1} m$ if only the direct route was available to the investor. However, as a tax-minimizing indirect route becomes available, the tax agency's revenue decreases by $\frac{c}{r}\left(t_{n 1}-t_{n j}\right)$.

For residence country 1 and source country $n$ with a unique tax-minimizing indirect route $1, i, \ldots, j, n$, the tax rate spread $s_{n 1}$ is defined as the difference of withholding tax rates imposed by country $n$ in the direct route and in the indirect route, that is, $s_{n 1}=t_{n 1}-t_{n j}$. The equilibrium loss of tax revenue is determined by the tax rate spread $s_{n 1}$.

Remark 2. If there are $\ell \geq 2$ tax-minimizing indirect routes, and if each tax-minimizing indirect route is played with equal probability $\frac{c}{r m} \cdot \frac{1}{\ell}$, in equilibrium, the tax agency's payoff is $t_{n 1} m-\frac{c}{r} \frac{1}{\ell} \sum_{k=1}^{\ell}\left(t_{n 1}-t_{n j_{k}}\right)$, where $j_{k}$ is the 
last pass-through country in each tax-minimizing indirect route $1, i_{k}, \ldots, j_{k}, n$ for $k=1, \ldots, \ell$. The equilibrium loss of tax revenue is $\frac{c}{r} \frac{1}{\ell} \sum_{k=1}^{\ell}\left(t_{n 1}-t_{n j_{k}}\right)$.

For residence country 1 and source country $n$, if there are $\ell \geq 2$ taxminimizing indirect routes, the tax rate spread $s_{n 1}$ is defined as the average difference of withholding tax rates imposed by country $n$ in the direct route and in the indirect routes, that is, $s_{n 1}=\frac{1}{\ell} \sum_{k=1}^{\ell}\left(t_{n 1}-t_{n j_{k}}\right)$. The equilibrium loss of tax revenue is determined by the tax rate spread $s_{n 1}$, provided that each tax-minimizing indirect route is played with equal probability.

The tax agency can raise more revenue by adopting the equilibrium random audit strategy than by sticking to pure strategies. In equilibrium the tax agency's payoff is $t_{n 1} m-\frac{c}{r} s_{n 1}$ and the investor's payoff is $\left(1-t_{n 1}\right)\left(1-t_{1}\right) m$. To compare payoffs, suppose that the tax agency is not allowed to use any random audit strategy due to certain statutory or administrative constraints.

First, consider a case where the tax agency does not audit the investor at all, and knowing this, the investor always uses a tax-minimizing indirect route $b^{*}=1, i, \ldots, j, n$. In this case, the tax agency's payoff is $t_{n j} m$ and the investor's payoff is $\left(1-t\left(b^{*}\right)\right)\left(1-t_{1}\right) m$. Because $c<r m$ implies $t_{n j} m<$ $t_{n 1} m-\frac{c}{r} s_{n 1}$, the tax agency raises more revenue by adopting the equilibrium random audit strategy. However, because $t\left(b^{*}\right)<t_{n 1}$, the investor earns less in equilibrium.

Second, consider another case where the tax agency always audits the investor, and knowing this, the investor always chooses the direct route. In this case, the tax agency's payoff is $t_{n 1} m-c$ and the investor's payoff is $\left(1-t_{n 1}\right)\left(1-t_{1}\right) m$. While the investor earns the same payoff in equilibrium, the tax agency raises more revenue if the penalty tax rate is greater than the tax rate spread. This is because $r>s_{n 1}$ implies $t_{n 1} m-c<t_{n 1} m-\frac{c}{r} s_{n 1}$. However, if $r<s_{n 1}$, the tax agency raises less revenue in equilibrium. This observation is summarized in the following remark.

Remark 3. If the penalty tax rate is greater than the tax rate spread, the tax agency raises more revenue by adopting the equilibrium random audit strategy than by sticking to non-random audit strategies. 
Table 1. Comparative statics

\begin{tabular}{|c|c|c|}
\hline $\begin{array}{c}\text { parameter } \\
\text { increase }\end{array}$ & $\begin{array}{c}\text { audit } \\
\text { probability } p\end{array}$ & $\begin{array}{c}\text { indirect-route } \\
\text { probability } q\end{array}$ \\
\hline$t\left(b^{*}\right)$ & $\downarrow$ & - \\
\hline$t_{n 1}$ & $\uparrow$ & - \\
\hline$t_{1}$ & $\downarrow$ & - \\
\hline$r$ & $\downarrow$ & $\downarrow$ \\
\hline$c$ & - & $\uparrow$ \\
\hline$m$ & - & $\downarrow$ \\
\hline
\end{tabular}

The comparative statics of the unique equilibrium shows interesting implications, as summarized in Table 1 .

As the tax rate matrix $T$ changes, if the tax rate $t\left(b^{*}\right)$ of a tax-minimizing indirect route $b^{*}$ increases, while the other parameters are fixed, the equilibrium probability $p$ of the tax agency auditing the investor decreases, i.e., the tax agency audits the investor less frequently. However, the equilibrium probability $q$ of the investor choosing tax-minimizing indirect routes remains unchanged. This is because the investor stays indifferent between the direct route and tax-minimizing indirect routes as the tax agency adjusts the equilibrium audit probability $p$.

If the tax rate $t_{n 1}$ of the direct route increases, then $p$ increases, i.e., the tax agency audits the investor more frequently. If the tax rate $t_{1}$ of the residence country increases, then $p$ decreases, i.e., the tax agency audits the investor less frequently. In both cases, however, $q$ remains unaffected.

As the penalty tax rate $r$ increases, while the other parameters are fixed, both $p$ and $q$ decrease. In other words, the tax agency audits the investor less frequently, and the investor chooses tax-minimizing indirect routes less frequently.

As the audit cost $c$ increases, $q$ increases, i.e., the investor chooses taxminimizing indirect routes more frequently. As the investor's income $m$ increases in the source country, $q$ decreases, i.e., the investor chooses taxminimizing indirect routes less frequently. In these cases, however, $p$ remains the same. 


\section{Application}

In this section I analyze the structure of tax-minimizing investment routes in a real-world network of tax treaties between fifteen selected countries: Belgium (BE), Bermuda (BM), Cayman Islands (KY), China (CN), Hong Kong (HK), Ireland (IE), Japan (JP), South Korea (KR), Luxembourg (LU), the Netherlands (NL), Saudi Arabia (SA), Singapore (SG), Switzerland (CH), the United Kingdom (GB), and the United States (US). ${ }^{9}$ Based on this analysis, network centrality measures are introduced to assess the importance of a country in tax-minimizing investment routes. I also discuss the implications of my analysis for the prevention of treaty shopping.

\subsection{Tax-minimizing routes}

Tax treaties between countries, as well as their national tax laws, specify rates of withholding tax on various types of income, such as dividends, interest, royalties, and capital gains. The rates of withholding tax can be reduced by tax treaties. In the context of international taxation, a withholding tax refers to a tax on income and on capital imposed by a source country. Here I focus on the rates of withholding tax on dividends by presuming that investors establish companies to earn and remit their income as dividends.

Table 2 shows the matrix of withholding tax rates as a percentage. ${ }^{10}$ The tax rate $t_{i j}$ is applied if dividends are paid from country $i$ to country $j$. For example, in Table 2, the BE-BM rate is 25 percent, which is applied when a company in Belgium pays out dividends directly to an entity in Bermuda. Note that the tax rate matrix in Table 2 is asymmetric. Even if the BE-BM rate is 25 percent, the BM-BE rate is zero percent.

\footnotetext{
${ }^{9}$ This list of countries can be categorized as follows: large countries (in terms of GDP) such as the United States, China, Japan, and the United Kingdom; medium-sized countries such as South Korea, the Netherlands, Saudi Arabia, Switzerland, and Belgium; small countries with developed financial sectors such as Singapore, Hong Kong, Ireland, and Luxembourg; and tax haven countries such as Bermuda and Cayman Islands.

${ }^{10}$ This matrix is constructed from the PwC Worldwide Tax Summaries database (website: www.taxsummaries.pwc.com) and based on minimum withholding tax rates. A minimum rate is often applied when an investor holds at least a certain percentage of shares.
} 
Table 2. Tax rate matrix

\begin{tabular}{|c|c|c|c|c|c|c|c|c|c|c|c|c|c|c|c|}
\hline & $\mathrm{BE}$ & $\mathrm{BM}$ & $\mathrm{KY}$ & $\mathrm{CN}$ & $\mathrm{HK}$ & $\mathrm{IE}$ & $\mathrm{JP}$ & $\mathrm{KR}$ & $\mathrm{LU}$ & $\mathrm{NL}$ & $\mathrm{SA}$ & $\mathrm{SG}$ & $\mathrm{CH}$ & $\mathrm{GB}$ & $\mathrm{US}$ \\
\hline $\mathrm{BE}$ & - & 25 & 25 & 5 & 0 & 0 & 0 & 0 & 0 & 0 & 25 & 0 & 0 & 0 & 0 \\
\hline $\mathrm{BM}$ & 0 & - & 0 & 0 & 0 & 0 & 0 & 0 & 0 & 0 & 0 & 0 & 0 & 0 & 0 \\
\hline $\mathrm{KY}$ & 0 & 0 & - & 0 & 0 & 0 & 0 & 0 & 0 & 0 & 0 & 0 & 0 & 0 & 0 \\
\hline $\mathrm{CN}$ & 5 & 10 & 10 & - & 5 & 5 & 10 & 5 & 5 & 5 & 5 & 5 & 5 & 5 & 10 \\
\hline $\mathrm{HK}$ & 0 & 0 & 0 & 0 & - & 0 & 0 & 0 & 0 & 0 & 0 & 0 & 0 & 0 & 0 \\
\hline $\mathrm{IE}$ & 0 & 0 & 0 & 0 & 0 & - & 0 & 0 & 0 & 0 & 0 & 0 & 0 & 0 & 0 \\
\hline JP & 7 & 7 & 7 & 7 & 5 & 7 & - & 5 & 5 & 0 & 5 & 5 & 0 & 0 & 0 \\
\hline $\mathrm{KR}$ & 15 & 20 & 20 & 5 & 10 & 10 & 5 & - & 10 & 10 & 5 & 10 & 5 & 5 & 10 \\
\hline LU & 0 & 0 & 0 & 0 & 0 & 0 & 0 & 0 & - & 0 & 0 & 0 & 0 & 0 & 0 \\
\hline NL & 0 & 15 & 15 & 5 & 0 & 0 & 0 & 10 & 0 & - & 5 & 0 & 0 & 0 & 0 \\
\hline SA & 5 & 5 & 5 & 5 & 5 & 0 & 5 & 5 & 5 & 5 & - & 5 & 5 & 5 & 5 \\
\hline SG & 0 & 0 & 0 & 0 & 0 & 0 & 0 & 0 & 0 & 0 & 0 & - & 0 & 0 & 0 \\
\hline CH & 0 & 35 & 35 & 10 & 0 & 0 & 0 & 5 & 0 & 0 & 35 & 5 & - & 0 & 5 \\
\hline GB & 0 & 0 & 0 & 0 & 0 & 0 & 0 & 0 & 0 & 0 & 0 & 0 & 0 & - & 0 \\
\hline US & 0 & 30 & 30 & 10 & 30 & 5 & 0 & 10 & 5 & 0 & 30 & 30 & 0 & 0 & - \\
\hline
\end{tabular}

There is no withholding tax on dividends in seven countries: Bermuda (BM), Cayman Islands (KY), Hong Kong (HK), Ireland (IE), Luxembourg (LU), Singapore (SG), and the United Kingdom (GB). This implies that investors can minimize tax on dividends by investing directly to these countries. However, the other countries impose withholding taxes on dividends, whose rates can be reduced by tax treaties: Belgium (BE), China $(\mathrm{CN})$, Japan (JP), South Korea (KR), the Netherlands (NL), Saudi Arabia (SA), Switzerland $(\mathrm{CH})$, and the United States (US). Investors may be able to minimize tax on dividends by investing indirectly to these countries, e.g., by investing through intermediary entities established in other countries.

Given the tax rate matrix in Table 2, tax-minimizing investment routes can be obtained for each pair of residence countries and source countries. To highlight the effect of tax treaty rates on the structure of tax-minimizing investment routes, I assume that every country $i$ maintains a sufficiently low tax rate $t_{i}=\epsilon>0$. Note that in Table 2 every source country $i$ sets the lowest tax treaty rate $t_{i j}$ for some country $j$ with no withholding tax. For instance, when Belgium (BE) is the source country, the lowest tax treaty rate is zero percent, and it is applied for countries with no withholding tax, such as Hong Kong (HK), Ireland (IE), Luxembourg (LU), Singapore (SG), and the United 
Kingdom (GB). Once investors transfer their income to these countries, they can remit it, with no withholding tax, to their residence country. So it only makes investors pay more tax to add another pass-through country. Therefore, every tax-minimizing route passes through at most one country. In other words, if an indirect route passes through two or more countries, the indirect route is not tax-minimizing. This observation is summarized in the following remark.

Remark 4. Given a tax rate matrix, if each country sets the lowest tax treaty rate for some country with no withholding tax, and if each country maintains a sufficiently low tax rate, then every tax-minimizing route passes through at most one country.

Table 3 shows tax-minimizing investment routes. In Table 3, residence countries are in the top row, whereas source countries are in the leftmost column. Each asterisk $(*)$ indicates that a direct route is tax-minimizing. However, if an indirect route is tax-minimizing, the corresponding pass-through country is specified in Table 3, and the corresponding tax rate spread is shown as a percentage in parentheses.

The most striking case is observed when Saudi Arabia (SA) is the source country. As shown in Table 2, Saudi Arabia (SA) generally imposes a fivepercent withholding tax on dividends with only the exception of Ireland (IE). The SA-IE rate is zero percent. Moreover, Ireland (IE) imposes no withholding tax on dividends. Therefore, investors pay no tax at all on dividends by establishing an intermediary entity in Ireland (IE) and investing indirectly to Saudi Arabia (SA). For example, if an investor is a resident of the United States (US) and plans to invest in Saudi Arabia (SA),

$$
\mathrm{US} \rightarrow \mathrm{IE} \rightarrow \mathrm{SA}
$$

is the only tax-minimizing route and it is an indirect route. 
Table 3. Tax-minimizing investment routes

Note: $*$ direct route

\begin{tabular}{|c|c|c|c|c|c|c|c|c|c|c|c|c|c|c|c|}
\hline & $\mathrm{BE}$ & $\mathrm{BM}$ & KY & $\mathrm{CN}$ & HK & IE & JP & KR & $\mathrm{LU}$ & NL & $\mathrm{SA}$ & SG & $\mathrm{CH}$ & GB & US \\
\hline $\mathrm{BE}$ & - & $\begin{array}{l}\text { HK } \\
\text { IE } \\
\text { LU } \\
\text { SG } \\
\text { GB } \\
(25)\end{array}$ & $\begin{array}{l}\text { HK } \\
\text { IE } \\
\text { LU } \\
\text { SG } \\
\text { GB } \\
(25)\end{array}$ & $\begin{array}{l}\text { HK } \\
\text { IE } \\
\text { LU } \\
\text { SG } \\
\text { GB } \\
(5)\end{array}$ & $*$ & $*$ & * & $*$ & $*$ & * & $\begin{array}{l}\text { HK } \\
\text { IE } \\
\text { LU } \\
\text { SG } \\
\text { GB } \\
(25)\end{array}$ & $*$ & * & * & * \\
\hline $\mathrm{BM}$ & * & - & $*$ & $*$ & $*$ & * & * & * & * & * & * & $*$ & * & $*$ & * \\
\hline KY & * & * & - & * & * & * & * & * & * & * & * & * & * & * & * \\
\hline $\mathrm{CN}$ & $*$ & $\begin{array}{l}\text { HK } \\
\text { IE } \\
\text { LU } \\
\text { SG } \\
\text { GB } \\
(5)\end{array}$ & $\begin{array}{l}\text { HK } \\
\text { IE } \\
\text { LU } \\
\text { SG } \\
\text { GB } \\
(5)\end{array}$ & - & $*$ & $*$ & $\begin{array}{l}\text { BE } \\
\text { HK } \\
\text { IE } \\
\text { LU } \\
\text { NL } \\
\text { SG } \\
\text { CH } \\
\text { GB } \\
(5)\end{array}$ & $*$ & * & $*$ & * & $*$ & $*$ & * & $\begin{array}{l}\text { BE } \\
\text { HK } \\
\text { IE } \\
\text { LU } \\
\text { NL } \\
\text { SG } \\
\text { GB } \\
(5)\end{array}$ \\
\hline HK & * & * & * & * & - & * & * & * & * & $*$ & $*$ & $*$ & $*$ & * & $*$ \\
\hline $\mathrm{IE}$ & * & $*$ & * & * & $*$ & - & $*$ & * & * & * & * & $*$ & * & * & * \\
\hline JP & $\begin{array}{l}\mathrm{NL} \\
\mathrm{CH} \\
\mathrm{GB} \\
\mathrm{US} \\
(7)\end{array}$ & $\begin{array}{l}\text { GB } \\
(7)\end{array}$ & $\begin{array}{l}\text { GB } \\
(7)\end{array}$ & $\begin{array}{l}\text { GB } \\
(7)\end{array}$ & $\begin{array}{l}\text { NL } \\
\mathrm{CH} \\
\mathrm{GB} \\
(5)\end{array}$ & $\begin{array}{l}\text { NL } \\
\text { CH } \\
\text { GB } \\
(7)\end{array}$ & - & $\begin{array}{l}\text { GB } \\
(5)\end{array}$ & $\begin{array}{l}\text { NL } \\
\text { CH } \\
\text { GB } \\
(5)\end{array}$ & $*$ & $\begin{array}{l}\text { GB } \\
(5)\end{array}$ & $\begin{array}{l}\text { NL } \\
\text { GB } \\
(5)\end{array}$ & $*$ & * & * \\
\hline $\mathrm{KR}$ & $\begin{array}{l}\mathrm{CH} \\
\mathrm{GB} \\
(10)\end{array}$ & $\begin{array}{l}\text { GB } \\
(15)\end{array}$ & $\begin{array}{l}\text { GB } \\
(15)\end{array}$ & $*$ & $\begin{array}{l}\mathrm{CH} \\
\mathrm{GB} \\
(5)\end{array}$ & $\begin{array}{l}\text { SA } \\
\text { CH } \\
\text { GB } \\
(5) \\
\end{array}$ & * & - & $\begin{array}{l}\text { CH } \\
\text { GB } \\
(5)\end{array}$ & $\begin{array}{l}\text { JP } \\
\text { CH } \\
\text { GB } \\
(5)\end{array}$ & * & $\begin{array}{l}\mathrm{CH} \\
\mathrm{GB} \\
(5)\end{array}$ & $*$ & * & $\begin{array}{l}\text { JP } \\
\text { GB } \\
(5)\end{array}$ \\
\hline $\mathrm{LU}$ & * & * & $*$ & $*$ & $*$ & * & $*$ & * & - & * & $*$ & $*$ & $*$ & * & * \\
\hline NL & * & $\begin{array}{l}\text { HK } \\
\text { IE } \\
\text { LU } \\
\text { SG } \\
\text { GB } \\
(15)\end{array}$ & $\begin{array}{l}\text { HK } \\
\text { IE } \\
\text { LU } \\
\text { SG } \\
\text { GB } \\
(15)\end{array}$ & $\begin{array}{l}\text { HK } \\
\text { IE } \\
\text { LU } \\
\text { SG } \\
\text { GB } \\
(5)\end{array}$ & $*$ & $*$ & * & $\begin{array}{l}\mathrm{BE} \\
\mathrm{HK} \\
\mathrm{IE} \\
\mathrm{LU} \\
\mathrm{SG} \\
\mathrm{GB} \\
(10)\end{array}$ & * & - & $\begin{array}{l}\text { HK } \\
\text { IE } \\
\text { LU } \\
\text { SG } \\
\text { GB } \\
(5)\end{array}$ & $*$ & * & * & * \\
\hline SA & $\begin{array}{l}\mathrm{IE} \\
(5)\end{array}$ & $\begin{array}{l}\mathrm{IE} \\
(5)\end{array}$ & $\begin{array}{l}\mathrm{IE} \\
(5)\end{array}$ & $\begin{array}{l}\mathrm{IE} \\
(5)\end{array}$ & $\begin{array}{l}\mathrm{IE} \\
(5)\end{array}$ & $*$ & $\begin{array}{l}\mathrm{IE} \\
(5)\end{array}$ & $\begin{array}{l}\text { IE } \\
(5)\end{array}$ & $\begin{array}{l}\mathrm{IE} \\
(5)\end{array}$ & $\begin{array}{l}\text { IE } \\
(5)\end{array}$ & - & $\begin{array}{l}\text { IE } \\
(5)\end{array}$ & $\begin{array}{l}\mathrm{IE} \\
(5)\end{array}$ & $\begin{array}{l}\mathrm{IE} \\
(5)\end{array}$ & $\begin{array}{l}\mathrm{IE} \\
(5)\end{array}$ \\
\hline SG & * & * & * & * & * & * & * & * & * & * & $*$ & - & * & * & $*$ \\
\hline $\mathrm{CH}$ & * & $\begin{array}{l}\text { HK } \\
\text { IE } \\
\text { LU } \\
\text { GB } \\
(35)\end{array}$ & $\begin{array}{l}\text { HK } \\
\text { IE } \\
\text { LU } \\
\text { GB } \\
(35)\end{array}$ & $\begin{array}{l}\text { HK } \\
\text { IE } \\
\text { LU } \\
\text { GB } \\
(10)\end{array}$ & $*$ & * & * & $\begin{array}{l}\mathrm{BE} \\
\mathrm{HK} \\
\mathrm{IE} \\
\mathrm{LU} \\
\mathrm{GB} \\
(5)\end{array}$ & * & * & $\begin{array}{l}\text { HK } \\
\text { IE } \\
\text { LU } \\
\text { GB } \\
(35)\end{array}$ & $\begin{array}{l}\mathrm{BE} \\
\mathrm{HK} \\
\mathrm{IE} \\
\mathrm{LU} \\
\mathrm{NL} \\
\mathrm{GB} \\
(5)\end{array}$ & - & * & $\begin{array}{l}\text { BE } \\
\text { HK } \\
\text { IE } \\
\text { JP } \\
\text { LU } \\
\text { NL } \\
\text { GB } \\
(5)\end{array}$ \\
\hline GB & $*$ & $*$ & $*$ & $*$ & * & * & * & * & * & * & * & * & * & - & * \\
\hline US & $*$ & $\begin{array}{l}\text { GB } \\
(30)\end{array}$ & $\begin{array}{l}\text { GB } \\
(30)\end{array}$ & $\begin{array}{l}\text { GB } \\
(10)\end{array}$ & $\begin{array}{l}\mathrm{BE} \\
\mathrm{NL} \\
\mathrm{CH} \\
\mathrm{GB} \\
(30)\end{array}$ & $\begin{array}{l}\mathrm{BE} \\
\mathrm{NL} \\
\mathrm{CH} \\
\mathrm{GB} \\
(5)\end{array}$ & * & $\begin{array}{c}\mathrm{BE} \\
\mathrm{GB} \\
(10)\end{array}$ & $\begin{array}{l}\mathrm{BE} \\
\mathrm{NL} \\
\mathrm{CH} \\
\mathrm{GB} \\
(5)\end{array}$ & * & $\begin{array}{l}\text { GB } \\
(30)\end{array}$ & $\begin{array}{l}\mathrm{BE} \\
\mathrm{NL} \\
\mathrm{GB} \\
(30)\end{array}$ & $*$ & * & - \\
\hline
\end{tabular}


However, there may be more than one tax-minimizing indirect route. For example, from Bermuda (BM) to Belgium (BE), there are five tax-minimizing indirect routes:

$$
\mathrm{BM} \rightarrow \mathrm{HK} \rightarrow \mathrm{BE}
$$

Here HK can be replaced with any one of IE, LU, SG, or GB. Interestingly, these five indirect routes pass through countries with no withholding tax on dividends. Among all tax-minimizing indirect routes (177 routes) shown in Table 3, there are 134 indirect routes (about 75 percent) passing through such countries. These indirect routes can maximize an investor's after-tax income because some source countries set the minimum tax treaty rate for these countries.

In addition there are 43 tax-minimizing indirect routes passing through countries that generally impose withholding taxes. Interestingly, most of these indirect routes (38 routes; about 21 percent of all tax-minimizing indirect routes) pass through either Belgium (BE), the Netherlands (NL), or Switzerland $(\mathrm{CH})$. These countries maintain tax treaties favorable to certain residence countries, such as Japan. For example, from Japan (JP) to China $(\mathrm{CN})$, there are eight tax-minimizing indirect routes:

$$
\mathrm{JP} \rightarrow \mathrm{BE} \rightarrow \mathrm{CN}
$$

Here BE can be replaced with any one of HK, IE, LU, NL, SG, CH, or GB. China $(\mathrm{CN})$ has tax treaties with these countries that offer a five-percent withholding tax rate, which is the minimum rate among all tax treaty rates of China. In turn, Belgium (BE), the Netherlands (NL), and Switzerland $(\mathrm{CH})$ have tax treaties with Japan (JP) under which withholding tax rates are reduced to zero percent. While generally imposing withholding taxes, by maintaining tax treaties preferential for certain residence countries, Belgium (BE), the Netherlands (NL), and Switzerland (CH) play a significant role as a pass-through country in international investments.

In Table 3 it is worthwhile to note that tax-minimizing routes may be asymmetric. Even if a direct route $j \rightarrow i$ is tax-minimizing, $i \rightarrow j$ may not 
be tax-minimizing. Even if an indirect route $j \rightarrow k \rightarrow i$ is tax-minimizing, $i \rightarrow k \rightarrow j$ may not be tax-minimizing. For example, $\mathrm{JP} \rightarrow \mathrm{BE} \rightarrow \mathrm{CN}$ is tax-minimizing but not $\mathrm{CN} \rightarrow \mathrm{BE} \rightarrow \mathrm{JP}$.

Based on the analysis in Table 3, in the Appendix, network diagrams are presented to show the patterns of tax-minimizing investment routes to each source country.

\subsection{Centrality measures}

To assess and compare the importance of a country in tax-minimizing investment routes, network centrality measures are introduced. ${ }^{11}$ Each centrality measure can be defined from the perspective of a source country as well as from that of all source countries in aggregate.

First, for each source country $i$, a centrality measure $\alpha_{i}(k)$ of a country $k \neq i$ is defined as

$$
\alpha_{i}(k)=\sum_{j \neq i, k} \ell_{i j}(k)
$$

where $\ell_{i j}(k)$ is the number of tax-minimizing indirect routes from residence country $j$ to source country $i$ passing through country $k$. Let $\alpha_{i}(i)=0$. Because every tax-minimizing route passes through at most one country, as shown in Table 3 , if there is a tax-minimizing route $j \rightarrow k \rightarrow i, \ell_{i j}(k)=1$. Otherwise, $\ell_{i j}(k)=0$. An aggregate centrality measure $\alpha(k)$ is defined as the sum of $\alpha_{i}(k)$ over all source countries, that is, $\alpha(k)=\sum_{i} \alpha_{i}(k)$. For example, from Table 3, we observe that four tax-minimizing indirect routes pass through Ireland (IE) and head to China $(\mathrm{CN})$, i.e., $\alpha_{\mathrm{CN}}(\mathrm{IE})=4$. In aggregate, $\alpha(\mathrm{IE})=33$.

Second, for each source country $i$, a centrality measure $\beta_{i}(k)$ of a country $k \neq i$ is defined as

\footnotetext{
${ }^{11}$ For more detailed discussion on network centrality, see Jackson (2008).
} 


$$
\beta_{i}(k)=\sum_{j \neq i, k} \frac{\ell_{i j}(k)}{\ell_{i j}}
$$

where $\ell_{i j}$ is the number of all tax-minimizing indirect routes from residence country $j$ to source country $i$. Let $\beta_{i}(i)=0$. An aggregate centrality measure $\beta(k)$ is defined as the sum of $\beta_{i}(k)$ over all source countries, i.e., $\beta(k)=$ $\sum_{i} \beta_{i}(k)$, and called the betweenness centrality of country $k$. From Table 3 , we can check that $\beta_{\mathrm{CN}}(\mathrm{IE})=\frac{1}{5}+\frac{1}{5}+\frac{1}{8}+\frac{1}{7} \approx 0.67$ and $\beta(\mathrm{IE})=16.94$.

Third, for each source country $i$, a centrality measure $\gamma_{i}(k)$ of a country $k \neq i$ is defined as

$$
\gamma_{i}(k)=\sum_{j \neq i, k} \frac{s_{i j} \ell_{i j}(k)}{\ell_{i j}}
$$

where $s_{i j}$ is the tax rate spread for residence country $j$ and source country $i$. Let $\gamma_{i}(i)=0$. An aggregate centrality measure $\gamma(k)$ is defined as the sum of $\gamma_{i}(k)$ over all source countries, that is, $\gamma(k)=\sum_{i} \gamma_{i}(k)$. In other words, $\gamma(k)$ is the betweenness centrality weighted by tax rate spreads. From Table 3 , we can check that $\gamma_{\mathrm{CN}}(\mathrm{IE})=\frac{5}{5}+\frac{5}{5}+\frac{5}{8}+\frac{5}{7} \approx 3.34$ and $\gamma(\mathrm{IE})=125.30$.

These centrality measures are calculated and presented as follows. Table 4 (a) shows centrality measures when $i=\mathrm{CN}$. For other source countries, centrality measures are presented in the Appendix. Table 4 (b) shows aggregate centrality measures. For $\beta$ and $\gamma$, numbers are rounded to the nearest hundredth.

From the perspective of China, as shown in Table 4 (a), Hong Kong (HK), Ireland (IE), Luxembourg (LU), Singapore (SG), and the United Kingdom (GB) are ranked on the top by the three centrality measures. These countries are followed by Belgium (BE), the Netherlands (NL), and Switzerland (CH) in centrality rankings.

From Table 4 (b) we observe that some countries have no or little importance as a pass-through country: Bermuda (BM), Cayman Islands (KY), China (CN), Japan (JP), South Korea (KR), Saudi Arabia (SA), and the 
United States (US). It is rather puzzling to see that Bermuda and Cayman Islands play no role as a pass-through country. However, as indicated in Table 2 , the reason may be that many countries maintain higher withholding tax rates to the residents of Bermuda and Cayman Islands.

We also observe that the United Kingdom (GB) and Ireland (IE) are ranked first and second, respectively, by the three aggregate centrality measures. These two countries are followed by Hong Kong (HK), Luxembourg $(\mathrm{LU})$, and Switzerland $(\mathrm{CH})$ in aggregate centrality rankings. However, each centrality measure ranks countries in a different way. For example, Switzerland $(\mathrm{CH})$ is ranked third by $\beta(k)$ but ranked fifth by $\alpha(k)$. Belgium (BE) is ranked seventh by $\gamma(k)$ but ranked eighth by $\alpha(k)$.

Table 4. Centrality measures

(a) China

\begin{tabular}{|c|r|r|r|}
\hline$k$ & $\alpha_{i}(k)$ & $\beta_{i}(k)$ & $\gamma_{i}(k)$ \\
\hline $\mathrm{BE}$ & 2 & 0.27 & 1.34 \\
\hline $\mathrm{BM}$ & 0 & 0 & 0 \\
\hline $\mathrm{KY}$ & 0 & 0 & 0 \\
\hline $\mathrm{CN}$ & 0 & 0 & 0 \\
\hline $\mathrm{HK}$ & 4 & 0.67 & 3.34 \\
\hline $\mathrm{IE}$ & 4 & 0.67 & 3.34 \\
\hline $\mathrm{JP}$ & 0 & 0 & 0 \\
\hline $\mathrm{KR}$ & 0 & 0 & 0 \\
\hline $\mathrm{LU}$ & 4 & 0.67 & 3.34 \\
\hline $\mathrm{NL}$ & 2 & 0.27 & 1.34 \\
\hline $\mathrm{SA}$ & 0 & 0 & 0 \\
\hline $\mathrm{SG}$ & 4 & 0.67 & 3.34 \\
\hline $\mathrm{CH}$ & 1 & 0.13 & 0.63 \\
\hline $\mathrm{GB}$ & 4 & 0.67 & 3.34 \\
\hline $\mathrm{US}$ & 0 & 0 & 0 \\
\hline
\end{tabular}

(b) Aggregate

\begin{tabular}{|c|r|r|r|}
\hline$k$ & $\alpha(k)$ & $\beta(k)$ & $\gamma(k)$ \\
\hline $\mathrm{BE}$ & 11 & 2.53 & 30.55 \\
\hline $\mathrm{BM}$ & 0 & 0 & 0 \\
\hline $\mathrm{KY}$ & 0 & 0 & 0 \\
\hline $\mathrm{CN}$ & 0 & 0 & 0 \\
\hline $\mathrm{HK}$ & 20 & 3.94 & 60.30 \\
\hline $\mathrm{IE}$ & 33 & 16.94 & 125.30 \\
\hline $\mathrm{JP}$ & 3 & 0.98 & 4.88 \\
\hline $\mathrm{KR}$ & 0 & 0 & 0 \\
\hline $\mathrm{LU}$ & 20 & 3.94 & 60.30 \\
\hline $\mathrm{NL}$ & 13 & 3.41 & 32.80 \\
\hline $\mathrm{SA}$ & 1 & 0.33 & 1.67 \\
\hline $\mathrm{SG}$ & 13 & 2.43 & 29.01 \\
\hline $\mathrm{CH}$ & 14 & 4.79 & 33.88 \\
\hline $\mathrm{GB}$ & 48 & 21.44 & 274.55 \\
\hline $\mathrm{US}$ & 1 & 0.25 & 1.75 \\
\hline
\end{tabular}




\subsection{Policy implications}

Countries may prevent or at least mitigate treaty shopping by amending tax treaties to include anti-treaty shopping provisions. ${ }^{12}$ For instance, by adding limitation on benefits clauses into tax treaties, countries make certain residents eligible for treaty benefits while making the rest ineligible. Moreover, by adding main purpose test clauses, countries can deny treaty benefits of the residents who deliberately organize transactions to obtain the benefits.

These countries may spend significant time and effort to amend tax treaties, because they have to renegotiate the terms of tax treaties with other contracting countries. Therefore, rather than trying to amend all tax treaties without anti-treaty shopping provisions, countries may concentrate on a group of tax treaties that can be abused for treaty shopping. For example, Saudi Arabia would be able to prevent treaty shopping by amending the tax treaty with Ireland, because Ireland is the only pass-through country in tax-minimizing investment routes to Saudi Arabia, as shown in Table 3.

Countries need to amend tax treaties with all possible pass-through countries, because otherwise investors will switch to safer tax-minimizing indirect routes, which will not be affected by the amended treaties. In other words, if there are multiple tax-minimizing indirect routes to a country, it is necessary for the country to amend tax treaties with all possible pass-through countries in the indirect routes. For example, if China amends the tax treaty with Luxembourg, investors will switch to other tax-minimizing indirect routes, which pass through either one of Hong Kong, Ireland, Singapore, and the United Kingdom.

However, it may not be a practical approach for a country to attempt to amend tax treaties simultaneously with all possible pass-through countries, because it is indeed an onerous task to renegotiate and amend a tax treaty. Thus, countries may assign priorities to certain tax treaties based on centrality measures, which are presented in Table 4 and in the Appendix. By following these priorities, countries may continue amending tax treaties

\footnotetext{
${ }^{12}$ For detailed discussion, see the commentary on Article 1 of OECD (2012).
} 
with all possible pass-through countries. But it will take significant time to complete all these amendments. In this regard, rather than relying on bilateral treaty negotiations, countries may initiate multilateral cooperation for amending tax treaties to include anti-treaty shopping provisions.

\section{Conclusion}

To consider treaty shopping as a strategic situation, in this paper, I develop a game-theoretic model in a network of tax treaties. The equilibrium of this model is characterized as a mixed-strategy Nash equilibrium. It is shown that a tax agency can raise more revenue by adopting the equilibrium random audit strategy than by sticking to non-random audits. However, the tax agency raises less revenue in equilibrium than when no treaty shopping is possible. This equilibrium loss of revenue is shown to be determined by the tax rate spread, which is defined as the difference of tax rates imposed by a source country in direct and indirect investment routes. I also analyze the structure of tax-minimizing investment routes in a real-world network of tax treaties between selected countries. To prevent treaty shopping effectively, countries need to amend tax treaties with all possible pass-through countries in taxminimizing investment routes by adding anti-treaty shopping provisions into tax treaties.

In this paper, for simplicity of analysis, I have made two implicit assumptions. For future research, it will be interesting to examine more realistic models by relaxing these assumptions.

The first assumption is that an investor's after-tax income is determined only by taxable income and tax rates. However, the after-tax income may also be affected by other systemic factors, such as foreign tax credit and deduction. For example, if an investor is a resident of a country with high tax rates and sufficiently generous foreign tax credit, the investor's after-tax income may not be critically affected by the choice of an investment route, because the amount of foreign taxes paid along the investment route will be deducted from tax liability in the residence country. 
The second assumption is that an investor earns his foreign income as dividends. However, the investor can also earn other types of income, such as interest, royalties, and capital gains. Thus, we can define various types of tax treaty networks, where tax rates depend on income types, and examine the structure of tax-minimizing routes in these networks. It will be interesting to study hybrid indirect routes along which types of income can be altered to further reduce tax, for example, from capital gains to dividends.

I hope to address these issues in my future research. 


\section{Appendix}

Based on the analysis in Table 3, figures are presented to show the patterns of tax-minimizing investment routes to each source country. In each figure, a source country is indicated by a black dot $(\bullet)$, whereas any other countries are indicated by white dots $(\circ)$. Each arrow $(\rightarrow)$ shows the direction of an investment route. Thus, a pass-through country can be identified as a white dot with incoming arrows. Figure A.1 shows tax-minimizing investment routes to Belgium, China, Japan, and South Korea.

Figure A.1. Tax-minimizing investment routes

(a) Belgium

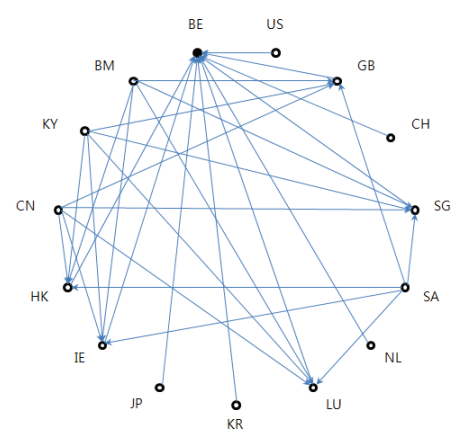

(c) Japan

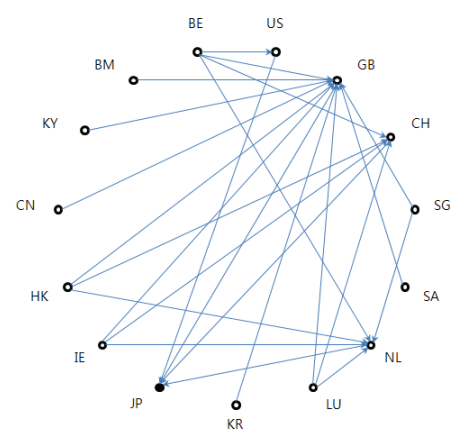

(b) China

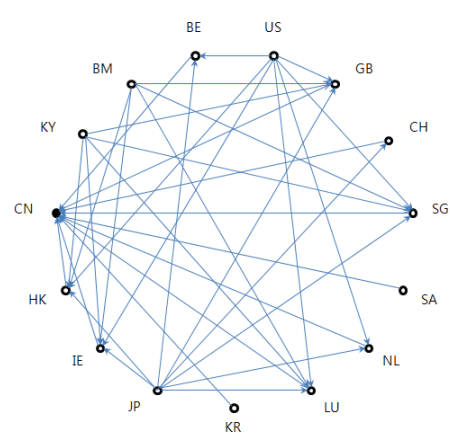

(d) South Korea

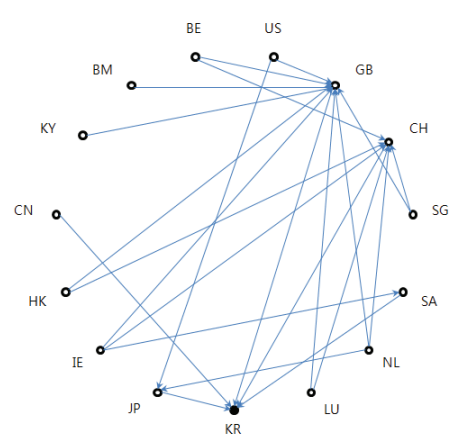


Figure A.2 shows tax-minimizing investment routes to the Netherlands, Saudi Arabia, Switzerland, and the United States.

Figure A.2. Tax-minimizing investment routes

(a) The Netherlands

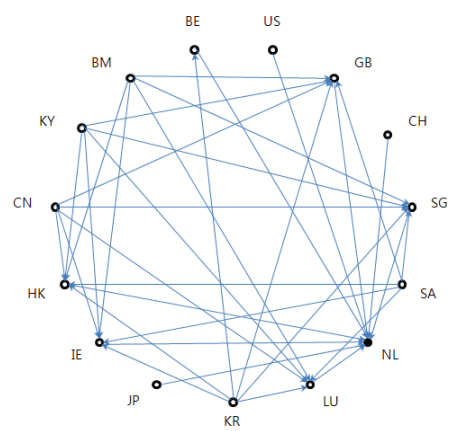

(c) Switzerland

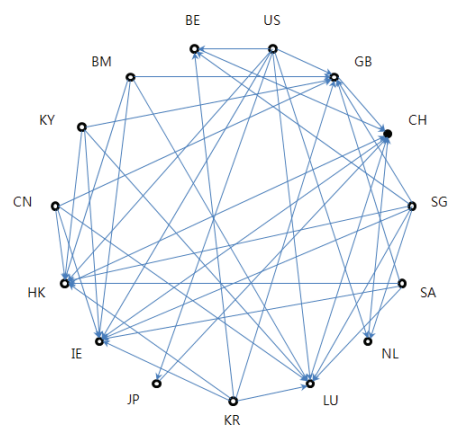

(b) Saudi Arabia

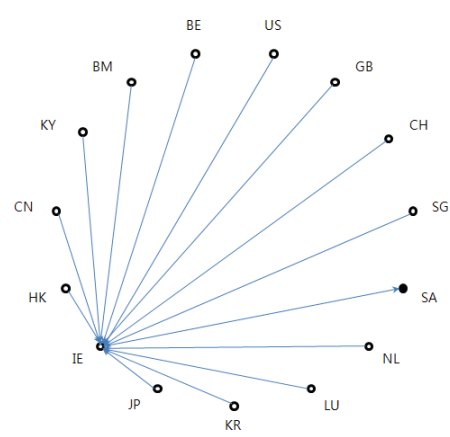

(d) The United States

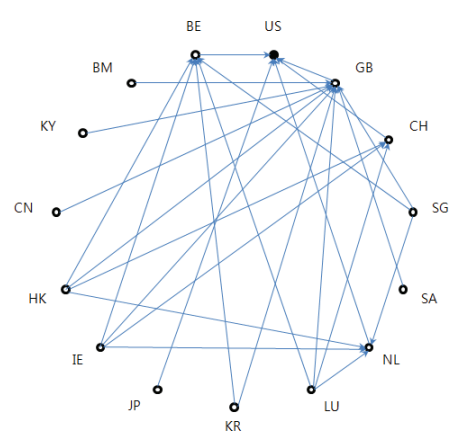

In addition to Table 4, for each source country, centrality measures are calculated as follows. For centrality measures $\beta$ and $\gamma$, numbers are rounded to the nearest hundredth. 
Table A.1. Centrality measures

(a) Belgium

\begin{tabular}{|c|r|r|r|}
\hline$k$ & $\alpha_{i}(k)$ & \multicolumn{1}{|c|}{$\beta_{i}(k)$} & \multicolumn{1}{|c|}{$\gamma_{i}(k)$} \\
\hline $\mathrm{BE}$ & 0 & 0 & 0 \\
\hline $\mathrm{BM}$ & 0 & 0 & 0 \\
\hline $\mathrm{KY}$ & 0 & 0 & 0 \\
\hline $\mathrm{CN}$ & 0 & 0 & 0 \\
\hline $\mathrm{HK}$ & 4 & 0.80 & 16.00 \\
\hline $\mathrm{IE}$ & 4 & 0.80 & 16.00 \\
\hline $\mathrm{JP}$ & 0 & 0 & 0 \\
\hline $\mathrm{KR}$ & 0 & 0 & 0 \\
\hline $\mathrm{LU}$ & 4 & 0.80 & 16.00 \\
\hline $\mathrm{NL}$ & 0 & 0 & 0 \\
\hline $\mathrm{SA}$ & 0 & 0 & 0 \\
\hline $\mathrm{SG}$ & 4 & 0.80 & 16.00 \\
\hline $\mathrm{CH}$ & 0 & 0 & 0 \\
\hline $\mathrm{GB}$ & 4 & 0.80 & 16.00 \\
\hline $\mathrm{US}$ & 0 & 0 & 0 \\
\hline
\end{tabular}

(c) Japan

\begin{tabular}{|c|r|r|r|}
\hline$k$ & $\alpha_{i}(k)$ & $\beta_{i}(k)$ & \multicolumn{1}{|c|}{$\gamma_{i}(k)$} \\
\hline $\mathrm{BE}$ & 0 & 0 & 0 \\
\hline $\mathrm{BM}$ & 0 & 0 & 0 \\
\hline $\mathrm{KY}$ & 0 & 0 & 0 \\
\hline $\mathrm{CN}$ & 0 & 0 & 0 \\
\hline $\mathrm{HK}$ & 0 & 0 & 0 \\
\hline $\mathrm{IE}$ & 0 & 0 & 0 \\
\hline $\mathrm{JP}$ & 0 & 0 & 0 \\
\hline $\mathrm{KR}$ & 0 & 0 & 0 \\
\hline $\mathrm{LU}$ & 0 & 0 & 0 \\
\hline $\mathrm{NL}$ & 5 & 1.75 & 9.92 \\
\hline $\mathrm{SA}$ & 0 & 0 & 0 \\
\hline $\mathrm{SG}$ & 0 & 0 & 0 \\
\hline $\mathrm{CH}$ & 4 & 1.25 & 7.42 \\
\hline $\mathrm{GB}$ & 10 & 6.75 & 40.92 \\
\hline $\mathrm{US}$ & 1 & 0.25 & 1.75 \\
\hline
\end{tabular}

(b) China

\begin{tabular}{|c|r|r|r|}
\hline$k$ & $\alpha_{i}(k)$ & $\beta_{i}(k)$ & \multicolumn{1}{|c|}{$\gamma_{i}(k)$} \\
\hline $\mathrm{BE}$ & 2 & 0.27 & 1.34 \\
\hline $\mathrm{BM}$ & 0 & 0 & 0 \\
\hline $\mathrm{KY}$ & 0 & 0 & 0 \\
\hline $\mathrm{CN}$ & 0 & 0 & 0 \\
\hline $\mathrm{HK}$ & 4 & 0.67 & 3.34 \\
\hline $\mathrm{IE}$ & 4 & 0.67 & 3.34 \\
\hline $\mathrm{JP}$ & 0 & 0 & 0 \\
\hline $\mathrm{KR}$ & 0 & 0 & 0 \\
\hline $\mathrm{LU}$ & 4 & 0.67 & 3.34 \\
\hline $\mathrm{NL}$ & 2 & 0.27 & 1.34 \\
\hline $\mathrm{SA}$ & 0 & 0 & 0 \\
\hline $\mathrm{SG}$ & 4 & 0.67 & 3.34 \\
\hline $\mathrm{CH}$ & 1 & 0.13 & 0.63 \\
\hline $\mathrm{GB}$ & 4 & 0.67 & 3.34 \\
\hline $\mathrm{US}$ & 0 & 0 & 0 \\
\hline
\end{tabular}

(d) South Korea

\begin{tabular}{|c|r|r|r|}
\hline$k$ & $\alpha_{i}(k)$ & \multicolumn{1}{|c|}{$\beta_{i}(k)$} & \multicolumn{1}{|c|}{$\gamma_{i}(k)$} \\
\hline $\mathrm{BE}$ & 0 & 0 & 0 \\
\hline $\mathrm{BM}$ & 0 & 0 & 0 \\
\hline $\mathrm{KY}$ & 0 & 0 & 0 \\
\hline $\mathrm{CN}$ & 0 & 0 & 0 \\
\hline $\mathrm{HK}$ & 0 & 0 & 0 \\
\hline $\mathrm{IE}$ & 0 & 0 & 0 \\
\hline $\mathrm{JP}$ & 2 & 0.83 & 4.17 \\
\hline $\mathrm{KR}$ & 0 & 0 & 0 \\
\hline $\mathrm{LU}$ & 0 & 0 & 0 \\
\hline $\mathrm{NL}$ & 0 & 0 & 0 \\
\hline $\mathrm{SA}$ & 1 & 0.33 & 1.67 \\
\hline $\mathrm{SG}$ & 0 & 0 & 0 \\
\hline $\mathrm{CH}$ & 6 & 2.67 & 15.83 \\
\hline $\mathrm{GB}$ & 9 & 5.17 & 48.33 \\
\hline $\mathrm{US}$ & 0 & 0 & 0 \\
\hline
\end{tabular}


Table A.2. Centrality measures

(a) The Netherlands

\begin{tabular}{|c|r|r|r|}
\hline$k$ & $\alpha_{i}(k)$ & $\beta_{i}(k)$ & \multicolumn{1}{|c|}{$\gamma_{i}(k)$} \\
\hline $\mathrm{BE}$ & 1 & 0.17 & 1.67 \\
\hline $\mathrm{BM}$ & 0 & 0 & 0 \\
\hline $\mathrm{KY}$ & 0 & 0 & 0 \\
\hline $\mathrm{CN}$ & 0 & 0 & 0 \\
\hline $\mathrm{HK}$ & 5 & 0.97 & 9.67 \\
\hline $\mathrm{IE}$ & 5 & 0.97 & 9.67 \\
\hline $\mathrm{JP}$ & 0 & 0 & 0 \\
\hline $\mathrm{KR}$ & 0 & 0 & 0 \\
\hline $\mathrm{LU}$ & 5 & 0.97 & 9.67 \\
\hline $\mathrm{NL}$ & 0 & 0 & 0 \\
\hline $\mathrm{SA}$ & 0 & 0 & 0 \\
\hline $\mathrm{SG}$ & 5 & 0.97 & 9.67 \\
\hline $\mathrm{CH}$ & 0 & 0 & 0 \\
\hline $\mathrm{GB}$ & 5 & 0.97 & 9.67 \\
\hline $\mathrm{US}$ & 0 & 0 & 0 \\
\hline
\end{tabular}

(c) Switzerland

\begin{tabular}{|c|r|r|r|}
\hline$k$ & $\alpha_{i}(k)$ & $\beta_{i}(k)$ & \multicolumn{1}{|c|}{$\gamma_{i}(k)$} \\
\hline $\mathrm{BE}$ & 3 & 0.51 & 2.55 \\
\hline $\mathrm{BM}$ & 0 & 0 & 0 \\
\hline $\mathrm{KY}$ & 0 & 0 & 0 \\
\hline $\mathrm{CN}$ & 0 & 0 & 0 \\
\hline $\mathrm{HK}$ & 7 & 1.51 & 31.30 \\
\hline $\mathrm{IE}$ & 7 & 1.51 & 31.30 \\
\hline $\mathrm{JP}$ & 1 & 0.14 & 0.71 \\
\hline $\mathrm{KR}$ & 0 & 0 & 0 \\
\hline $\mathrm{LU}$ & 7 & 1.51 & 31.30 \\
\hline $\mathrm{NL}$ & 2 & 0.31 & 1.55 \\
\hline $\mathrm{SA}$ & 0 & 0 & 0 \\
\hline $\mathrm{SG}$ & 0 & 0 & 0 \\
\hline $\mathrm{CH}$ & 0 & 0 & 0 \\
\hline $\mathrm{GB}$ & 7 & 1.51 & 31.30 \\
\hline $\mathrm{US}$ & 0 & 0 & 0 \\
\hline
\end{tabular}

(b) Saudi Arabia

\begin{tabular}{|c|r|r|r|}
\hline$k$ & $\alpha_{i}(k)$ & \multicolumn{1}{|c|}{$\beta_{i}(k)$} & \multicolumn{1}{|c|}{$\gamma_{i}(k)$} \\
\hline $\mathrm{BE}$ & 0 & 0 & 0 \\
\hline $\mathrm{BM}$ & 0 & 0 & 0 \\
\hline $\mathrm{KY}$ & 0 & 0 & 0 \\
\hline $\mathrm{CN}$ & 0 & 0 & 0 \\
\hline $\mathrm{HK}$ & 0 & 0 & 0 \\
\hline $\mathrm{IE}$ & 13 & 13.00 & 65.00 \\
\hline $\mathrm{JP}$ & 0 & 0 & 0 \\
\hline $\mathrm{KR}$ & 0 & 0 & 0 \\
\hline $\mathrm{LU}$ & 0 & 0 & 0 \\
\hline $\mathrm{NL}$ & 0 & 0 & 0 \\
\hline $\mathrm{SA}$ & 0 & 0 & 0 \\
\hline $\mathrm{SG}$ & 0 & 0 & 0 \\
\hline $\mathrm{CH}$ & 0 & 0 & 0 \\
\hline $\mathrm{GB}$ & 0 & 0 & 0 \\
\hline $\mathrm{US}$ & 0 & 0 & 0 \\
\hline
\end{tabular}

(d) The United States

\begin{tabular}{|c|r|r|r|}
\hline$k$ & $\alpha_{i}(k)$ & $\beta_{i}(k)$ & \multicolumn{1}{|c|}{$\gamma_{i}(k)$} \\
\hline $\mathrm{BE}$ & 5 & 1.58 & 25.00 \\
\hline $\mathrm{BM}$ & 0 & 0 & 0 \\
\hline $\mathrm{KY}$ & 0 & 0 & 0 \\
\hline $\mathrm{CN}$ & 0 & 0 & 0 \\
\hline $\mathrm{HK}$ & 0 & 0 & 0 \\
\hline $\mathrm{IE}$ & 0 & 0 & 0 \\
\hline $\mathrm{JP}$ & 0 & 0 & 0 \\
\hline $\mathrm{KR}$ & 0 & 0 & 0 \\
\hline $\mathrm{LU}$ & 0 & 0 & 0 \\
\hline $\mathrm{NL}$ & 4 & 1.08 & 20.00 \\
\hline $\mathrm{SA}$ & 0 & 0 & 0 \\
\hline $\mathrm{SG}$ & 0 & 0 & 0 \\
\hline $\mathrm{CH}$ & 3 & 0.75 & 10.00 \\
\hline $\mathrm{GB}$ & 9 & 5.58 & 125.00 \\
\hline $\mathrm{US}$ & 0 & 0 & 0 \\
\hline
\end{tabular}




\section{References}

[1] Becker, Johannes, and Ronald B. Davies. 2014. "A Negotiation-Based Model of Tax-Induced Transfer Pricing." working paper.

[2] Blonigen, Bruce A., and Ronald B. Davies. 2004. "The Effects of Bilateral Tax Treaties on U.S. FDI Activity." International Tax and Public Finance, 11(5): 601-622.

[3] Bond, Eric W., and Larry Samuelson. 1989. "Strategic Behaviour and the Rules for International Taxation of Capital." Economic Journal, 99(398): 1099-1111.

[4] Chisik, Richard, and Ronald B. Davies. 2004. "Asymmetric FDI and TaxTreaty Bargaining: Theory and Evidence." Journal of Public Economics, 88(6): 1119-1148.

[5] Clausing, Kimberly A. 2009. "Multinational Firm Tax Avoidance and Tax Policy." National Tax Journal, 62(4): 703-725.

[6] Davies, Ronald B. 2003. "The OECD Model Tax Treaty: Tax Competition and Two-Way Capital Flows." International Economic Review, 44(2): 725-753.

[7] Desai, Mihir A., and Dhammika Dharmapala. 2009. "Taxes, Institutions and Foreign Diversification Opportunities." Journal of Public Economics, 93(5-6): 703-714.

[8] Desai, Mihir A., and Dhammika Dharmapala. 2011. "Dividend Taxes and International Portfolio Choice." Review of Economics and Statistics, 93(1): 266-284.

[9] Desai, Mihir A., C. Fritz Foley, and James R. Hines Jr. 2006. "The Demand for Tax Haven Operations." Journal of Public Economics, 90(3): $513-531$. 
[10] Dharmapala, Dhammika. 2008. "What Problems and Opportunities are Created by Tax Havens?" Oxford Review of Economic Policy, 24(4): 661-679.

[11] Dharmapala, Dhammika, and James R. Hines Jr. 2009. "Which Countries Become Tax Havens?" Journal of Public Economics, 93(9-10): 1058-1068.

[12] Feldstein, Martin, and David Hartman. 1979. "The Optimal Taxation of Foreign Source Investment Income." Quarterly Journal of Economics, 93(4): 613-629.

[13] Gravelle, Jane G. 2009. "Tax Havens: International Tax Avoidance and Evasion." National Tax Journal, 62(4): 727-753.

[14] Hines Jr., James R., and Eric M. Rice. 1994. "Fiscal Paradise: Foreign Tax Havens and American Business." Quarterly Journal of Economics, 109(1): 149-182.

[15] Hong, Qing, and Michael Smart. 2010. "In Praise of Tax Havens: International Tax Planning and Foreign Direct Investment." European Economic Review, 54(1): 82-95.

[16] Jackson, Matthew O. 2008. Social and Economic Networks. Princeton, NJ: Princeton University Press.

[17] Janeba, Eckhard. 1995. "Corporate Income Tax Competition, Double Taxation Treaties, and Foreign Direct Investment." Journal of Public Economics, 56(2): 311-325.

[18] Konan, Denise Eby. 1997. "Strategic Taxation of the Multinational Enterprise: A New Argument for Double Taxation." Journal of Public Economics, 63(2): 301-309.

[19] OECD. 2012. Model Tax Convention on Income and on Capital 2010. OECD Publishing. 
[20] OECD. 2013. Action Plan on Base Erosion and Profit Shifting. OECD Publishing.

[21] Slemrod, Joel, and John D. Wilson. 2009. "Tax Competition with Parasitic Tax Havens." Journal of Public Economics, 93(11-12): 1261-1270. 